\title{
Evaluation of groundwater suitability for irrigation in the coastal aquifer of Mnasra (Gharb, Morocco)
}

\author{
Nadia Aziane ${ }^{1}$, Achraf Khaddari ${ }^{2}$, Mohammed Ebn-Touhami ${ }^{1}$, Abdelmjid Zouahri ${ }^{3}$, Hakima Nassali ${ }^{1}$ \\ and Mohamed Salah Elyoubi ${ }^{1}$
}

\author{
${ }^{1}$ Ibn Tofail University, Faculty of Sciences, Department of chemistry, Laboratory Materials Engineering and \\ Environment: Modeling and Application, Kenitra, Morocco \\ ${ }^{2}$ Ibn Tofail University, Faculty of Sciences, Department of Geology, Natural Resources Geoscience Laboratory, \\ Kenitra, Morocco
}

${ }^{3}$ Institut National de la Recherche Agronomique, CRRAR, Département de l'Environnement et la Conservation des Ressources Naturelles- Rabat, Maroc

\begin{abstract}
The coastal area of the Gharb plain constitutes the only hydric resource for region in terms of domestic consumption and agricultural demand which does not cease to increase. It is a very productive and easily accessible groundwater resource, used extensively for irrigation by own pumping. This study was performed to understand the impact of groundwater quality on the crop yields and its suitability for the irrigation for 63 wells and 7 boreholes. Groundwater quality in Mnasra was studied based on different indices for irrigation. The values of SAR, Na \%, MAR, SSP, PI, RSC and TDS show that most of the samples fall under good to suitable category. Piper diagram reveals three facies: sodic, calcic and magnesic chlorinated. The results indicate that the order of cation dominance is $\mathrm{Na}>\mathrm{Ca}>\mathrm{Mg}>\mathrm{K}$, while anion dominance is in the order $\mathrm{Cl}>\mathrm{HCO}_{3}>\mathrm{SO}_{4}$. Stuyfzand's classification indicates that most of the waters analyzed are fresh with moderate alkalinity. Richard Plot indicates that groundwater in the study area is within the low salinity to low sodium hazard and medium salinity to low sodium hazard class (C2S1 and C3S1). Wilcox Plot shows groundwater to be within excellent to a good class.
\end{abstract}

Keywords: Irrigation, Groundwater, hydrogeochemical, agriculture, Mnasra, Morocco.

\section{Introduction}

Irrigation has made a substantial contribution to meeting the growing food needs of the population on the one hand, and to promote economic and social development around the irrigated areas, on the other hand, ${ }^{1-2}$. In arid and semi-arid areas, the supply of irrigation water is one of the determining factors for the expansion of agricultural production, both in terms of crop intensification and the extension of irrigated areas $^{3}$. However, these large-scale irrigation practices have changed the functioning of the soil, sometimes leading to a decline in soil fertility, productivity and environmental quality, thus jeopardizing the sustainability of the resource.

The coastal region of Mnasra, the geographical area of our study, is the most agricultural area of the Gharb plain, it is a very productive and easily accessible groundwater resource, is exploited in a fast way for irrigation by single pumping ${ }^{4}$. The number of wells dug in the aquifer, exceeding 20,000, shows its agricultural importance. Freshwater resources in such arid coastal aquifers are vulnerable to degradation due

*Corresponding author: Nadia Aziane

Email address: nadiaaziane@gmail.com

DOI: http://dx.doi.org/10.13171/mjc1020200222997nz to: (i) its proximity to seawater, (ii) scarce subsurface recharge and annual precipitation and, (iii) the sensitivity of fresh groundwater floating over deep saline water, due to pumping induces ${ }^{5}$.

Groundwater quality depends on the nature of recharging water, precipitation, subsurface and surface water and hydro-geochemical processes in aquifers $^{6-7}$, land-use/land-cover change ${ }^{8-13}$. Temporal changes in the constitution and origin of the water recharge, and the human factor, frequently cause periodic changes in groundwater quality 14-15. Groundwater quality degrades in twofold, first, due to geochemical reactions in the aquifers and soils and, second, time when it is supplied through improper canals/drainages for irrigation. Therefore, it is necessary to perform a regular assessment of irrigation and drinking water quality ${ }^{16-19}$. Irrigation demands sufficient water supply of good quality. The index based on composition and concentration of dissolved elements in water can be useful in determining its applicability for agricultural utilization ${ }^{20-22}$. The suitability of groundwater for irrigation depends on the nature of the mineral

Received July 8, 2020

Accepted September 9, 2020

Published February 22, 2020 
elements in the water and their impacts on both the soil and plants ${ }^{23-24}$. This study seeks to evaluate the quality and suitability of groundwater for irrigation in the region of Mnasra.

\section{Materials and method}

\subsection{Study site}

The Mnasra region is the most agricultural area of the Gharb plain, forming the geographical continuity along the Atlantic Ocean. It covers an area of $488 \mathrm{~km}^{2}$ between the city of Kenitra in the south, the Oued Sebou extended by the parallel line passing through Sidi Allal Tazi in the east, Merja Zerga near Moulay Bouselham in the north. The study area is an integral part of the Gharb Subsidized Sedimentary Basin. It is located in the contact zone between Morocco's two major structural areas: the primary meseta coastal, which gradually plunges south to the north, and the Rifain domain, which belongs to the Alpine domain around the Mediterranean. The geological building is formed at the base by a primary basement, composed of schists and quartzites, located at a depth of more than $2500 \mathrm{~m}$ in the center of the plain. A powerful marl series of up to $2000 \mathrm{~m}$ is deposited on the primary formations. This series of "blue marls" constitutes the impermeable floor of the Gharb aquifer system. From the Peliocen onwards, sedimentation became regressive, consisting of lumachelles, sandstone and conglomerates. On these formations are deposited over a thickness of $200 \mathrm{~m}$, Peliocen sediments of marine origin. They are located in the coastal zone and are made up of sands, sandstones and calcareous sandstones, in which thin clayey-silt levels are interspersed. These formations constitute a major aquifer reservoir (Fig. 1).

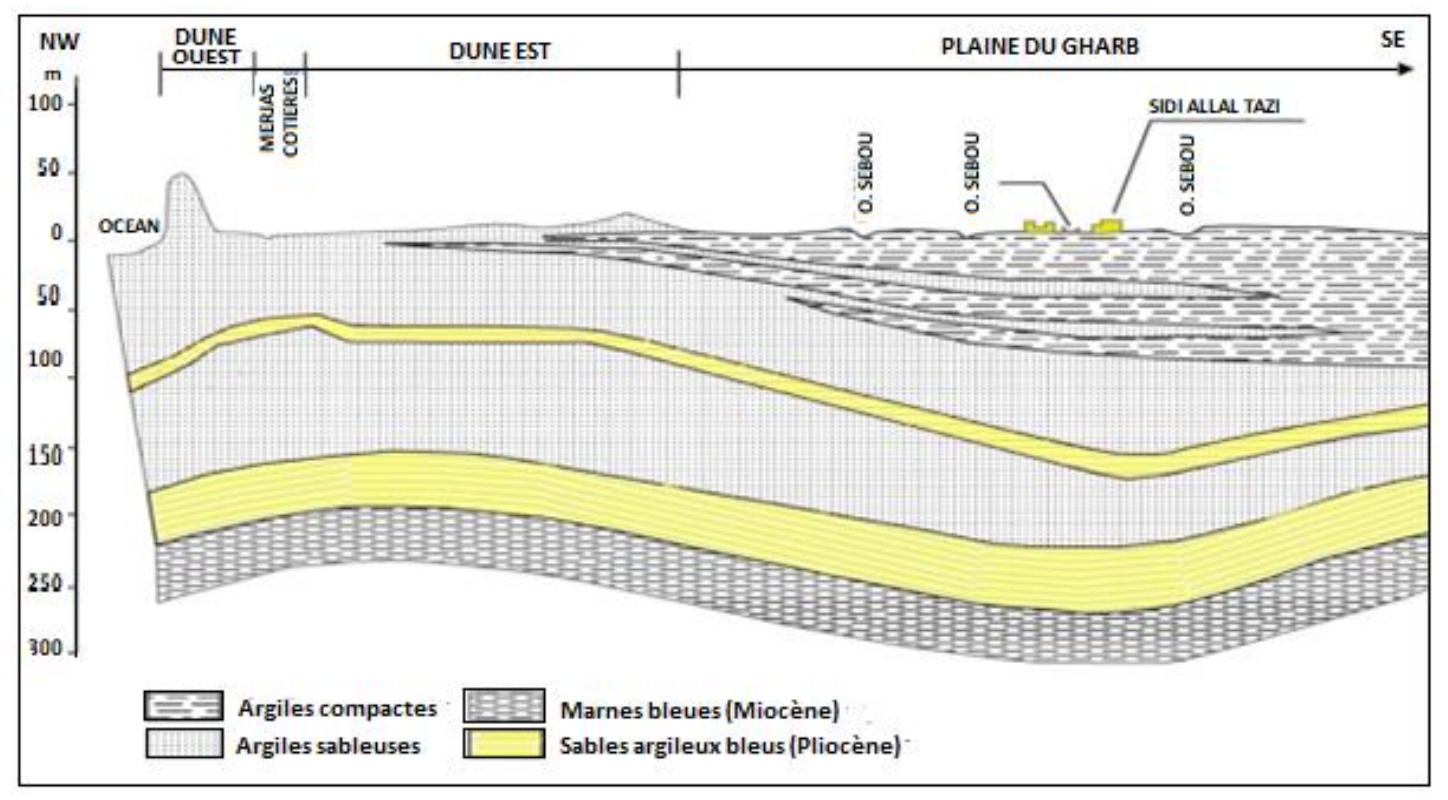

Figure 1. NW-SE geological section of the Gharb coastal zone 25

The aquifer system of the Gharb coastal zone can be presented by the succession of two different layers: a sandstone surface layer that has a thickness of between 5 and $10 \mathrm{~m}$ in the inland dunes, and between 20 and $30 \mathrm{~m}$ in the dune belt. Within this layer, we find the groundwater table characterized by a shallow depth at the level of the inland dunes ( 2 to $10 \mathrm{~m}$ ), and a somewhat depth in the coastal cordon (10 to $40 \mathrm{~m}$ ). The second layer containing the deep water table is very thick compared to the first and is mainly made of sandstone. The hydraulic communication between these two levels is carried out through a red clay-sand screen, whose thickness varies from 10 to $20 \mathrm{~m}^{26}$. It should also be noted that the soil of the region is occupied by heavy soils (vertisols and fluvisols). The sandy soils of the coastal zone cover about 39,000 ha or $15 \%$ of the area of the Gharb plain ${ }^{27}$. The climate is the Mediterranean with oceanic influence. It receives an average annual rainfall of about $551 \mathrm{~mm}$. The rainfall period extends from October to the end of
April, with a maximum for November, December and January. Mean temperatures range from $12^{\circ} \mathrm{C}$ in winter to $23^{\circ} \mathrm{C}$ in summer. Potential evaporation exceeds $150 \mathrm{~mm}$ during the dry months of June to September and is less than $80 \mathrm{~mm}$ during December to February ${ }^{28}$.

\subsection{Sampling and analysis}

A sampling campaign was carried out at 63 wells and 7 boreholes during June and July 2017. The choice of sampling sites was based primarily on two criteria: the depth of the aquifer and salinity levels of irrigation water.

Water samples were collected into 1-1 polyethylene bottles which were precleaned with concentrated hydrochloric acid and distilled water.

To assess the quality of well water and particularly salinity, the following analyses were performed: EC, $\mathrm{pH}$, total dissolved solids, and ionic balance. Measuring the EC of the water was carried out using 
the Orion laboratory conductivity meter, model 162 . The $\mathrm{pH}$ of the water was measured using the Metrohm pH meter, model 691. The total dissolved salts of the water were determined by the gravimetric method, evaporating a certain amount of water at $105^{\circ} \mathrm{C}^{29-30}$. The dosage of $\mathrm{Na}^{+}$and $\mathrm{K}^{+}$was carried out by flame photometry. $\mathrm{Ca}^{2+}$ and $\mathrm{Mg}^{2+}$ were analyzed by the EDTA titrimetric method ${ }^{31}$ Alkalinity as $\mathrm{CaCO}_{3}$ and
$\mathrm{HCO}_{3}$ were analysed by acid-base titration ${ }^{31}$. Sulfates were measured by nephelometric method ${ }^{31}$. Chloride $\left(\mathrm{Cl}^{-}\right)$was determined by standard $\mathrm{AgNO}_{3}$ titration ${ }^{29}$.

The validation of the results of the chemical analyzes was carried out by the verification of their percent charge balance errors (\% CBE). The latter was calculated according to the following equation ${ }^{32-33}$ :

$$
\operatorname{CBE}(\%)=([(\Sigma \text { cations }-\Sigma \text { anions })] /(\Sigma \text { cations }+\Sigma \text { anions })]) * 100 \quad \text { Eq.1 }
$$

Generally, the ion-balance error does not exceed $\pm 6 \%$.

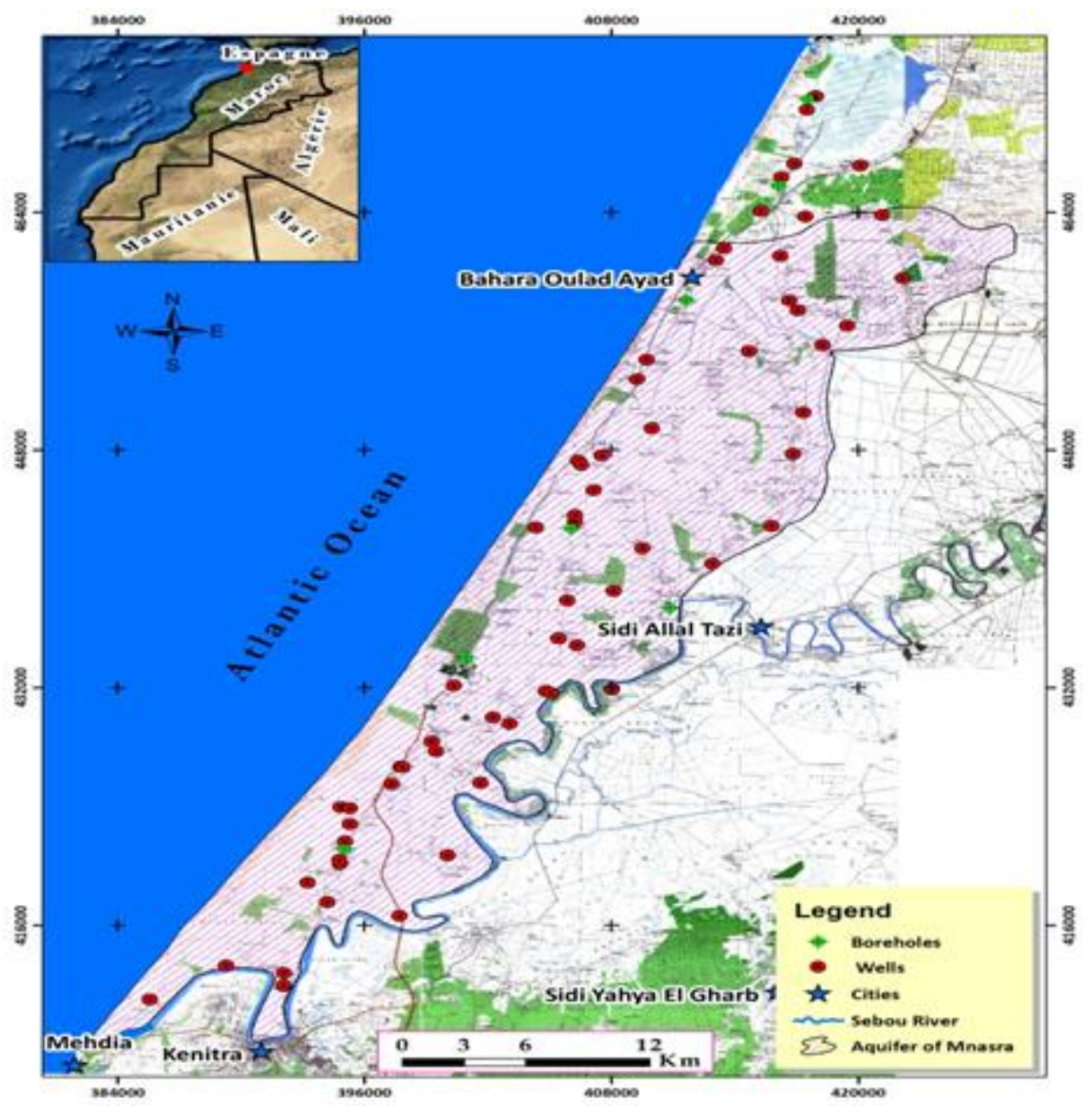

Figure 2. Location of sampling points

\subsection{Hydrochemical methods}

The hydrochemical methods for water characterization and classification adopted in this study are essentially based on the Piper diagram ${ }^{34}$ and the Stuyfzand classification ${ }^{35}$. The Piper diagram is used to represent cationic, anionic and global facies. Stuyfzand's classification is used to determine the chemical characteristics, namely the main type, type, subtype and class. The main type and type are determined based on chloride content and alkalinity index. Subtype classification is determined from cations and dominant anions. The class is determined from the sum of $\mathrm{Na}^{+}, \mathrm{K}^{+}$and $\mathrm{Mg}^{2+36}$ using Stufzand's equation 2, which calculates the Base Exchange Index (BEI):

$$
\mathrm{BEI}=\mathrm{Na}+\mathrm{K}-\mathbf{0 . 8 7 6 8 \mathrm { Cl }}
$$

Eq.2

\subsection{Qualitative methods}

Groundwater is widely used for irrigation in the Mnasra region. The quality of irrigation water is a reflection of its mineral composition and its effect on plants and soil ${ }^{37}$. The chemical composition of irrigation water directly affects plants and agricultural soils and leads to less productivity ${ }^{38}$.

Therefore, a water quality assessment for irrigation is very important for thriving agricultural production. In this study, irrigation water quality was evaluated by the parameters of the SAR, MAR, SSP \% Na, PI, RSC and TDS. These indicators were obtained using the following formulas ${ }^{39-42}$ :

- Sodium adsorption ratio

$\left.(\mathrm{SAR})=\mathrm{Na}^{+} / \sqrt{ }\left[\mathrm{Ca}^{2+}+\mathrm{Mg}^{2+}\right) / 2\right]$ Eq.3 
- Magnesium adsorption ratio

$(\mathrm{MAR})=\left[\mathrm{Mg}^{2+} /\left(\mathrm{Mg}^{2+}+\mathrm{Ca}^{2+}\right)\right]^{* 100}$

Eq.4

- Soluble Sodium Percentage

$\left.(\mathrm{SSP})=\left(\mathrm{Na}^{+} * 100\right) / \mathrm{Ca}^{2+}+\mathrm{Mg}^{2+}+\mathrm{Na}^{+}\right)$

Eq.5

- Percentage of sodium

$(\% \mathrm{Na})=\left[\left(\mathrm{Na}^{+}+\mathrm{K}^{+}\right) /\left(\mathrm{Ca}^{2+}+\mathrm{Mg}^{2+}+\mathrm{Na}^{+}+\mathrm{K}^{+}\right)\right]^{*} 100 \quad$ Eq.6

- Permeability index

$(\mathrm{PI})=(\mathrm{Na}+\sqrt{ } \mathrm{HCO} 3) /(\mathrm{Na}+\mathrm{Ca}+\mathrm{Mg}) * 100 \quad$ Eq.7

- Residual sodium carbonate

$(\mathrm{RSC})=\left(\mathrm{CO}_{3}{ }^{2-}+\mathrm{HCO}_{3}^{-}\right)-\left(\mathrm{Ca}^{2+}+\mathrm{Mg}^{2+}\right)$

Eq.8

- Total dissolved salts

$($ TDS $)=$ Sum of cations and anions

Where all ionic concentrations are expressed in meq/L.

\subsection{Regionalization of results}

The spatial distribution of indicators for assessing the irrigation suitability of Mnasra's groundwater is illustrated by graphical representations in the form of iso-content maps. The mapping of the spatial distribution of these parameters was carried out using an ArcView 3.2 GIS Geographic Information System. The spatial interpolation of these parameters is based on the geostatistical approach using the kriging method, which allows a linear estimation with the minimum variance ${ }^{43-44}$.

\section{Results and Discussions}

\subsection{Physico-chemical parameters}

The main descriptive statistics for groundwater EC, $\mathrm{pH}$, cations and anions are given in Table 1 . It is seen from this table that the water constituents are highly variable with respect to cationic and anionic constituents. However, this variability depends on the constituents. The most variable element is $\mathrm{K}$ with a coefficient of variation (CV) of $369,7 \%$, although it is a minor constituent with a mean value of $8,12 \mathrm{mg} / \mathrm{l}$ and values ranging between 0,19 and $250,24 \mathrm{mg} / \mathrm{l}$. this is due to its selective adsorption by clays ${ }^{45}$.

The second most variable constituent is $\mathrm{Na}$ with a $\mathrm{CV}$ of $188,1 \%$; it is the predominant cation with a mean of $108,43 \mathrm{mg} / \mathrm{l}$ and values varied from 16,31 to 1636 , $79 \mathrm{mg} / \mathrm{l}$. The third variable constituent is $\mathrm{Cl}$ with a $\mathrm{CV}$ of $158,7 \%$; it is the predominant anion with a mean of 194, $41 \mathrm{mg} / \mathrm{l}$ and values varied from 17, 75 to $2449,5 \mathrm{mg} / \mathrm{l}$. Generally, $\mathrm{Cl}^{-}$comes from weathering of silicate-rich rocks, excess application of fertilizer, seawater intrusion, and animal and human waste contribute $\mathrm{Cl}^{-}$to groundwater ${ }^{46-47}$.

Many other constituents have a variability of the same magnitude ranging from 42 to $58 \%$ : $\mathrm{CO}_{3}, \mathrm{Ca}, \mathrm{SO}_{4}$, $\mathrm{HCO}_{3}$ and $\mathrm{Mg}$. To summarize, the importance, in average, of cations is $\mathrm{Na}>\mathrm{Ca}>\mathrm{Mg}>\mathrm{K}$ while for anions, it is $\mathrm{Cl}>\mathrm{HCO}_{3}>\mathrm{SO}_{4}>\mathrm{CO}_{3}$. However, this importance may vary from one observation to another depending on the spatial location where the sample was taken, which in turn is the function of climate, parent material, anthropogenic activities, etc.

Table 1. Descriptive statistics for measured water quality parameters.

\begin{tabular}{|c|c|c|c|c|}
\hline Parameter & Min & Max & Mean & $\mathrm{CV}$ \\
\hline pH & 6,91 & 8,65 & 7,49 & 4,40 \\
\hline $\mathrm{CE}(\boldsymbol{\mu} \mathrm{S} / \mathrm{m})$ & 267 & 9870 & 1567 & 94,80 \\
\hline $\mathrm{Na}^{+}(\mathrm{mg} / \mathrm{l})$ & 16,31 & 1636,79 & 108,43 & 188,10 \\
\hline $\mathrm{Ca}^{2+}(\mathrm{mg} / \mathrm{l})$ & 8,02 & 144,36 & 60,35 & 42,60 \\
\hline $\mathrm{Mg}^{2+}(\mathrm{mg} / \mathrm{l})$ & 2,43 & 65,61 & 23,20 & 58,00 \\
\hline $\mathrm{K}^{+}(\mathrm{mg} / \mathrm{l})$ & 0,19 & 250,24 & 8,12 & 369,70 \\
\hline $\mathrm{Cl}^{-}(\mathrm{mg} / \mathrm{l})$ & 17,75 & 2449,5 & 194,41 & 158,70 \\
\hline $\mathrm{HCO}_{3}{ }^{-}(\mathrm{mg} / \mathrm{l})$ & 61 & 610 & 175,94 & 56,30 \\
\hline $\mathrm{SO}_{4}{ }^{2-}(\mathrm{mg} / \mathrm{l})$ & 0,48 & 47,62 & 25,92 & 49,70 \\
\hline $\mathrm{CO}_{3}^{2-}(\mathrm{mg} / \mathrm{l})$ & 0 & 15 & 0,643 & 42,50 \\
\hline
\end{tabular}

In comparing our results to some recently published research works, there is a difference in the order of the major cations and anions. For example, from a study based on 300 groundwater samples from India, Chaudhary (2018) ${ }^{48}$ found that the most abundant cation was $\mathrm{Na}$ followed by $\mathrm{Ca}$ whereas in our case, it was the same. In contrast, Srinivasamoorthy et al. (2014) ${ }^{49}$ found that, in a study of 87 groundwater samples in India, the most abundant anion was $\mathrm{HCO}_{3}$ followed by $\mathrm{Cl}$ compared to our study it was the inverse.

\subsection{Hydrochemical classification}

Based on chloride contents, 16 wells have the main fresh-salt type with code"B", 6 wells are brackish type with code"B"' and 45 wells are fresh-salt type with code"F" (Table 2). Based on the average of the chemical elements, the water subtype is characterized 
by the dominance of $\mathrm{Cl}^{-}, \mathrm{Na}^{+}$, and $\mathrm{HCO}_{3}{ }^{-}$. The concentrations of $\mathrm{HCO}_{3}{ }^{-}$measured vary between 1 and $10 \mathrm{meq} / \mathrm{l}$. As a result, the alkalinity of the water (types) is moderate to moderately low, it is generated by the dissolution of limestone $\left(\mathrm{CaCO}_{3}\right)^{50}$.

Table 2. Stufzand classification.

\begin{tabular}{|c|c|c|c|}
\hline Main type & Classification levels & Code & Number of samples \\
\hline Type & $\mathrm{Cl}^{-}(\mathrm{meq} / \mathrm{l})$ & & \\
\hline Very oligohaline & $<0,141$ & G & - \\
\hline Oligolhaline & $0,141-0,846$ & $\mathrm{~g}$ & 1 \\
\hline Fresh & $0,846-4,231$ & $\mathrm{~F}$ & 45 \\
\hline Fresh-brackish & $4,231-8,462$ & $\mathrm{f}$ & 16 \\
\hline Brackish & $8,462-28,206$ & $\mathrm{~B}$ & 6 \\
\hline Brackish-salt & $28,206-282,064$ & $\mathrm{~b}$ & 2 \\
\hline Salt & $282,64-564,127$ & $\mathrm{~S}$ & - \\
\hline \multirow[t]{2}{*}{ Hyperhaline } & $>564,127$ & $\mathrm{H}$ & - \\
\hline & $\mathrm{HCO}_{3}(\mathrm{meq} / \mathrm{l})$ & & \\
\hline Very low & $<0,5$ & $*$ & - \\
\hline Low & $0,5-1$ & 0 & 2 \\
\hline Moderately low & $1-2$ & 1 & 24 \\
\hline Moderate & $2-4$ & 2 & 35 \\
\hline Moderately high & $4-8$ & 3 & 7 \\
\hline High & $8-16$ & 4 & 2 \\
\hline Very high & $16-32$ & 5 & - \\
\hline Extremely high & $32-64$ & 6 & - \\
\hline Extremely high & $>64$ & 7 & - \\
\hline Classe & $(\mathrm{Na}+\mathrm{K}+\mathrm{Mg})(\mathrm{meq} / \mathrm{l})$ & & \\
\hline Deficit of $(\mathrm{Na}+\mathrm{K}+\mathrm{Mg})$ & $<-\sqrt{ } 1 / 2 \mathrm{Cl}$ & - & - \\
\hline Equilibrium of $(\mathrm{Na}+\mathrm{k}+\mathrm{Mg})$ & $\geq-\sqrt{ } 1 / 2 \mathrm{Cl}$ et $\leq 1 / 2 \mathrm{Cl}$ & 0 & - \\
\hline Surplus of $(\mathrm{Na}+\mathrm{k}+\mathrm{Mg})$ & $>1 / 2 \mathrm{Cl}$ & + & 70 \\
\hline
\end{tabular}

For the water class, Stuyfzand's equation 2 revealed a single code class $(+)$ for all water points. This is due to dissolution processes of carbonate rocks ${ }^{51}$; cationic exchanges involved ${ }^{50}$ as well as irrigation water and fertilizer inputs.

\subsection{Geochemical facies of water}

The projection of the water points in the Piper diagram showed that Mnasra's groundwater is different. Three geochemical facies emerged:

- Calcic chlorinated facies: the cationic composition is $\mathrm{Ca}^{2+}>\mathrm{Na}^{+}>\mathrm{Mg}^{2+}$ and $\mathrm{Ca}^{2+}>\mathrm{Mg}^{2+}>\mathrm{Na}^{+}(51,42$ $\%$ water), the anionic composition is $\mathrm{Cl}^{-}>\mathrm{HCO}_{3}^{-}>$ $\mathrm{SO}_{4}{ }^{2-}$ (100\% water);
- Magnesic chlorinated facies : the cationic composition is $\mathrm{Mg}^{2+}>\mathrm{Ca}^{+}>\mathrm{Na}^{+}$and $\mathrm{Mg}^{2+}>\mathrm{Na}^{+}>$ $\mathrm{Ca}^{2+}\left(10 \%\right.$ water) the anionic composition is $\mathrm{Cl}^{-}>$ $\mathrm{HCO}_{3}{ }^{-}>\mathrm{SO}_{4}^{2-}$ (100\% water);

- Sodic chlorinated facies: the cationic composition is $\mathrm{Na}^{+}>\mathrm{Mg}^{2+}>\mathrm{Ca}^{2+}$ and $\mathrm{Na}{ }^{+}>\mathrm{Ca}^{2+}>\mathrm{Mg}^{2+}(38.58$ \% water), the anionic composition is $\mathrm{Cl}^{-}>\mathrm{HCO}_{3}{ }^{-}>$ $\mathrm{SO}_{4}{ }^{2-}$ (100\% water).

The calcic and magnesic chlorinated are due to the presence of dunes. The sodic chlorinated facies could come from the marine intrusion and the infiltration of saltwater from the Sebou wadi and the surface water bodies on its banks (dayas and merjas) which are also brackish and that they can constitute a source of contamination of the waters of the Mnasra aquifer. 


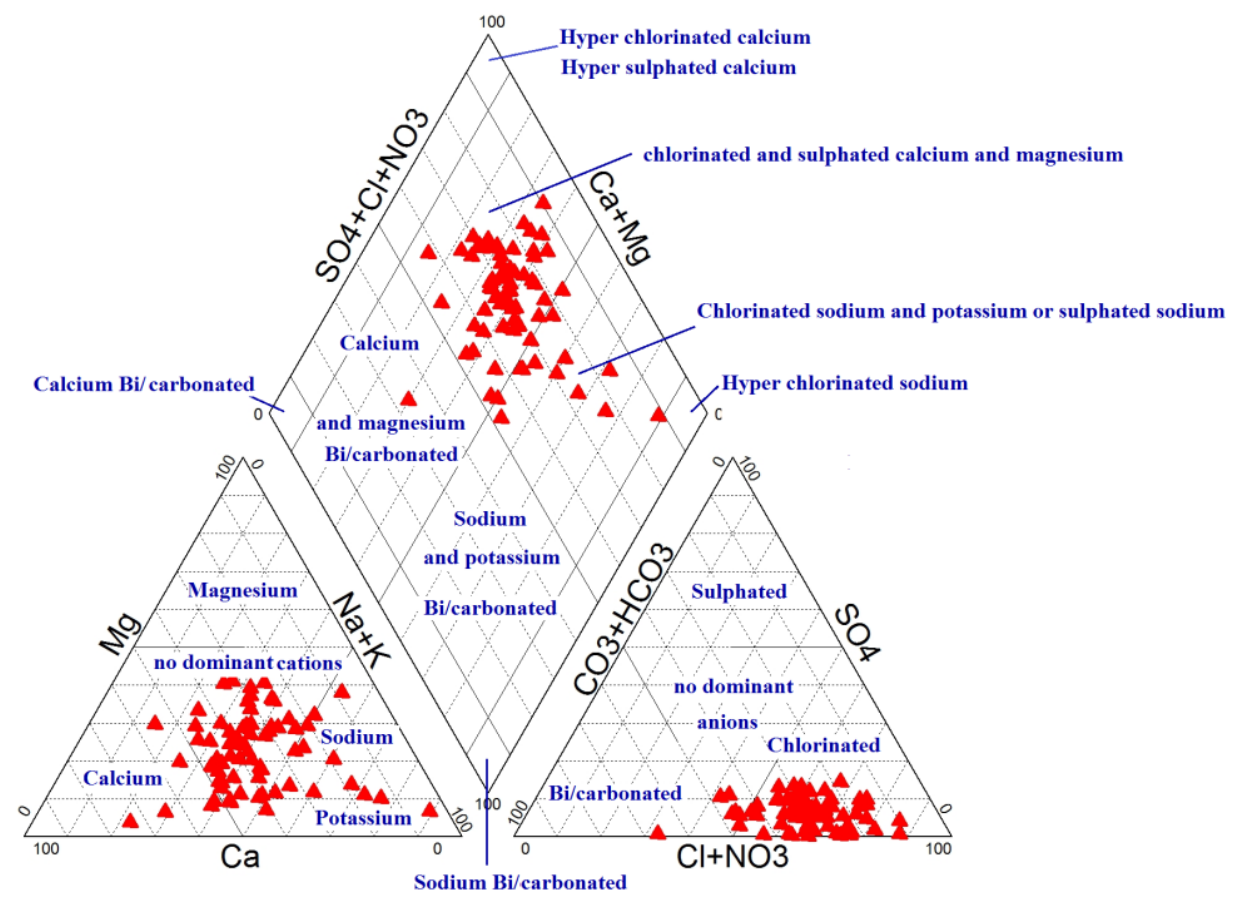

Figure 3. Piper diagram for irrigation water of Mnasra

\subsection{Spatial distribution of major elements}

Figures $4 \mathrm{a}, 4 \mathrm{~b}, 4 \mathrm{c}, 4 \mathrm{~d}$, and $4 \mathrm{e}$ show that the elements $\mathrm{Na}^{+}, \mathrm{Cl}-, \mathrm{Ca}^{2+}$ and $\mathrm{HCO}_{3}{ }^{-}$have relatively the same spatial distribution. The highest concentrations of these elements are observed in the south downstream of the Sebou River and in the northeast of the plain where salinity exceeds $6 \mathrm{~g} / \mathrm{l}$ to reach even $8 \mathrm{~g} / \mathrm{l}$. For these points, the groundwater level is close to the ground, which means that the groundwater is more exposed to evaporation and possible contamination by infiltration of irrigation water, which is a major source of salts. Salinization of water can also be attributed to marl, the return of irrigation water to the water resource and upwelling of saltwater trapped in sedimentary series in well catchment areas ${ }^{52}$.

The spatial variation of $4 \mathrm{c}$ calcium showed that the maximum concentrations are in the order of $144.36 \mathrm{mg} / \mathrm{l}$ and also observed downstream of the Sebou River and north of the plain. This variation takes into account that this $\mathrm{Ca}^{2+}$ ion is involved in several geochemical processes such as carbonate precipitation and/or basic exchange processes. The high concentrations of $\mathrm{Mg}^{2+}$ are located in the points near the dunes and downstream of the Sebou River, this is explained by the phenomenon of dedolomitization which would be caused by the irreversible dissolution of sulphates accompanied by the dissolution of dolomite and the precipitation of calcite ${ }^{53-54}$. As for the sulphate content, the examination of the spatial distribution map (Figure 4f) revealed low concentrations, while bicarbonate concentrations showed maximum concentrations of around $610 \mathrm{mg} / \mathrm{l}$ observed downstream of the Sebou wadi and northeast of the plain, due to the precipitation of carbonate formations. The high presence of chlorides and sodium in the groundwater of Mnasra can be the result of the combination of several important factors namely: the infiltration of saltwater from the Sebou River, the return of irrigation water to the water resource, direct marine intrusion is unlikely because the level of the water table remains above sea level. The discharge of domestic wastewater into poorly waterproofed septic tanks also contributes to the contamination of the lowest areas where the groundwater level is close to the ground. 

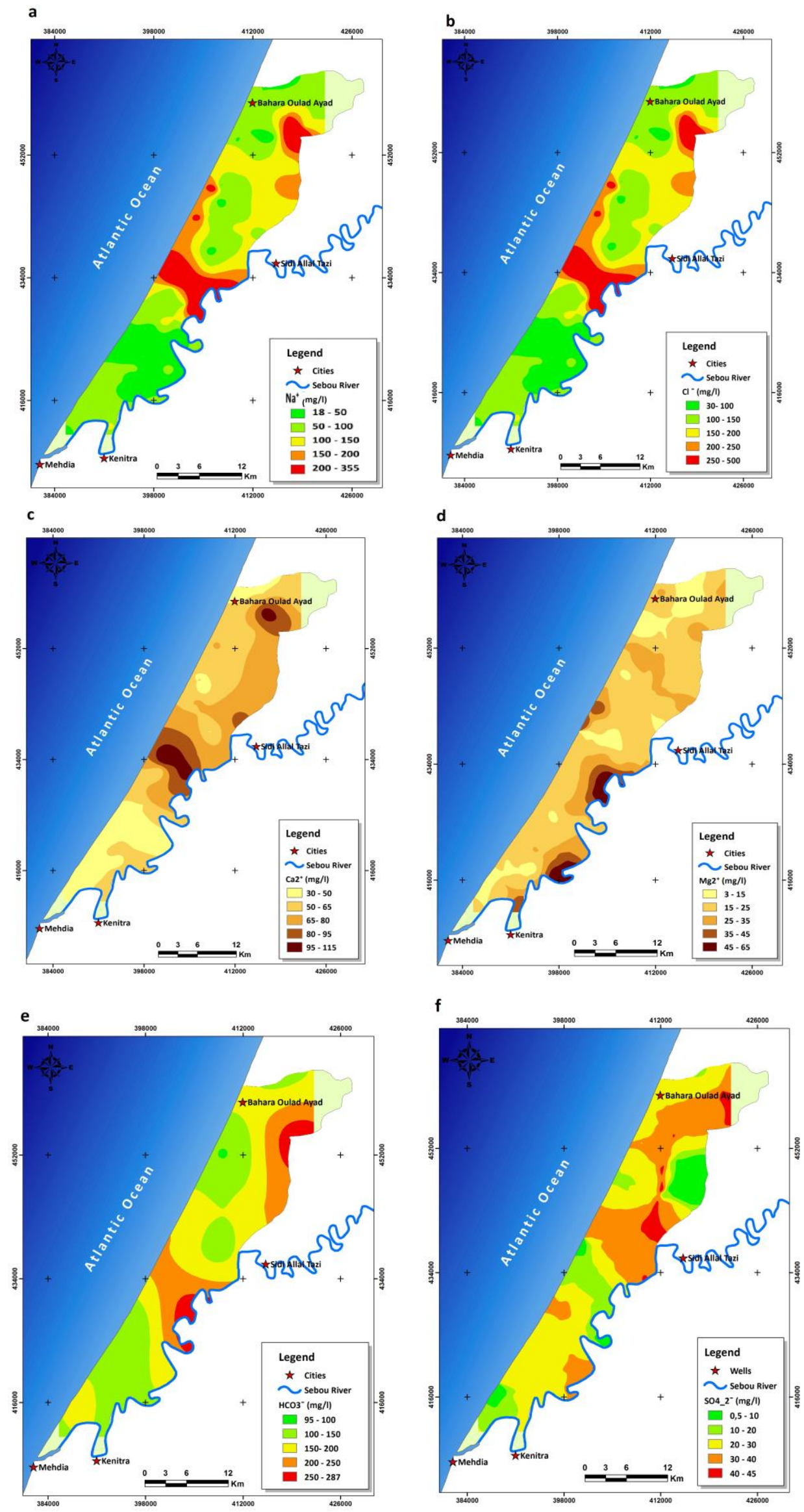

Figure 4. Spatial distribution of groundwater chemical elements of Mnasra 
3.5. Groundwater suitability for irrigation

Mnasra's groundwater are reported in Table 3.

The indices for assessing the irrigation suitability of

Table 3. Statistical results of SAR, \%Na, MAR, SSP, TDS, PI and RSC of the waters studied.

\begin{tabular}{|c|c|c|c|c|c|c|}
\hline Parameters & Max & Min & Average & $\begin{array}{l}\text { Standard } \\
\text { deviation }\end{array}$ & Standards & Water class \\
\hline \multirow{4}{*}{ SAR (meq/l) } & \multirow{4}{*}{34,31} & \multirow{4}{*}{0,50} & \multirow{4}{*}{2,75} & \multirow{4}{*}{4,21} & $<10$ & Excellent \\
\hline & & & & & $10-18$ & Good \\
\hline & & & & & $18-26$ & Doubtful \\
\hline & & & & & $>26$ & Unsuitable \\
\hline \multirow{5}{*}{$\mathrm{Na}(\%)$} & \multirow{5}{*}{89,24} & \multirow{5}{*}{15,20} & \multirow{5}{*}{41,12} & \multirow{5}{*}{12,55} & $<20$ & Excellent \\
\hline & & & & & $20-40$ & Good \\
\hline & & & & & $40-60$ & Permissible \\
\hline & & & & & $60-80$ & Doubtful \\
\hline & & & & & $>80$ & Unsuitable \\
\hline \multirow{2}{*}{ MAR (\%) } & \multirow{2}{*}{81,81} & \multirow{2}{*}{4,76} & \multirow{2}{*}{38,48} & \multirow{2}{*}{15,28} & $<50$ & Suitable \\
\hline & & & & & $>50$ & Unsuitable \\
\hline \multirow{2}{*}{ SSP (\%) } & \multirow{2}{*}{89,22} & \multirow{2}{*}{15,07} & \multirow{2}{*}{40,24} & \multirow{2}{*}{12,60} & $<50$ & Suitable \\
\hline & & & & & $>50$ & Unsuitable \\
\hline \multirow{4}{*}{ TDS (mg/l) } & \multirow{4}{*}{4923} & \multirow{4}{*}{345} & \multirow{4}{*}{710,54} & \multirow{4}{*}{638,94} & $<500$ & Desirable \\
\hline & & & & & $500-1000$ & Permissible \\
\hline & & & & & $<3000$ & Useful \\
\hline & & & & & $>3000$ & Unsuitable \\
\hline \multirow{3}{*}{ PI (\%) } & \multirow{3}{*}{93,02} & \multirow{3}{*}{43,36} & \multirow{3}{*}{61,69} & \multirow{3}{*}{11,08} & $>75$ & excellent \\
\hline & & & & & $25-75$ & Good \\
\hline & & & & & $<25$ & Unsuitable \\
\hline \multirow{3}{*}{$\mathrm{RSC}(\mathrm{meq} / \mathrm{l})$} & \multirow{3}{*}{0,60} & \multirow{3}{*}{$-5,80$} & \multirow{3}{*}{$-2,01$} & & $<1,25$ & Good \\
\hline & & & & 1,44 & $1,25-2,5$ & Doubtful \\
\hline & & & & & $>2,5$ & Unsuitable \\
\hline
\end{tabular}

The results showed that these waters are of good quality for agricultural purposes based on the quantitative parameters listed (SAR, MAR, SSP, PI, TDS and RSC) in Figure 5.

Regarding the risk related to sodium, the SARs of 69 wells are less than 10 , thus presenting minimal risk of sodium accumulation. However, only one well with a SAR more significant than 26 , which corresponds to high alkalinization risks ${ }^{55-56}$. High sodium levels in irrigation water can saturate the cation exchange complex, and destroy soil structure due to clay dispersion (Figure 5).

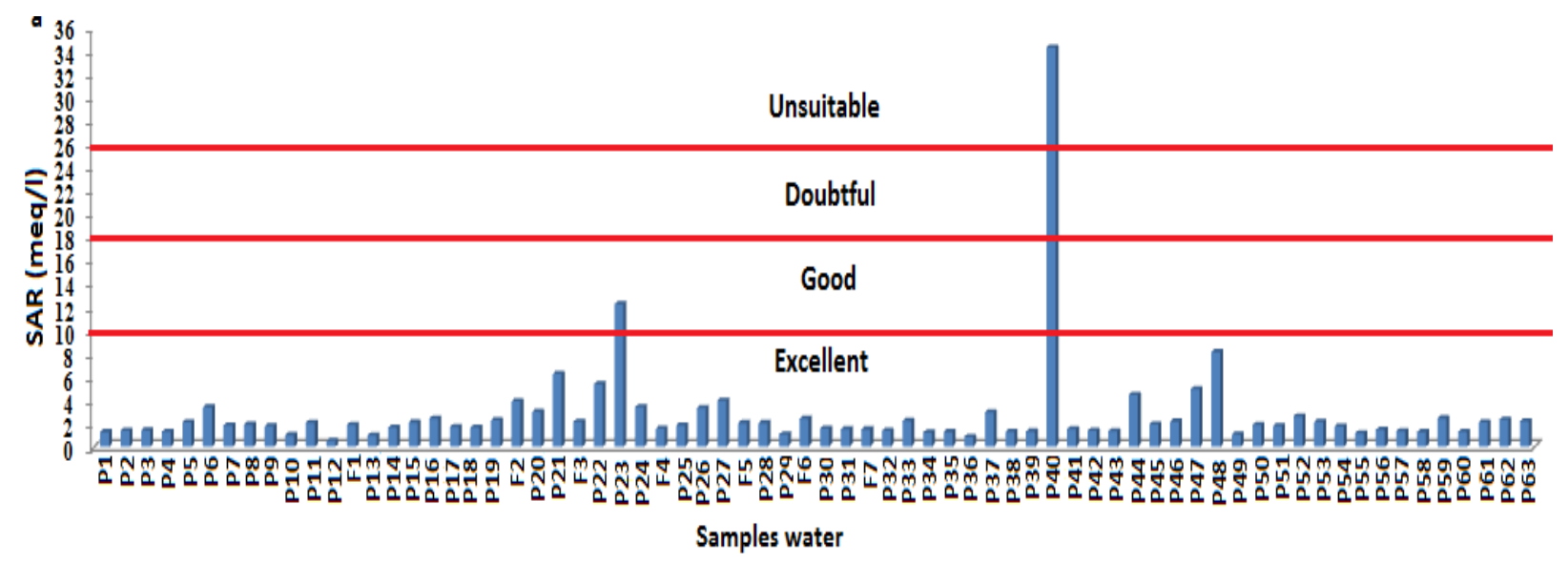

Figure 5. Comparison of sodium adsorption ratio Mnasra in aquifer groundwater with WHO standards 
The high SAR values were noted at points near Oued Sebou. Based on the overall salinity and SAR, the Richards diagram (Figure 6) was able to identify the presence of the following classes:

- Class C2S1 characterizes water that is good for irrigation and can be used without particular control for the irrigation of moderately salt-tolerant plants. It is found upstream of the slick near the inland dunes. This class appeared with only a small percentage not exceeding $(18,57 \%)$;

- Classes C3S1, C3S2 refer to water that is acceptable for irrigation of salt-tolerant crops on well-drained or permeable soils where salinity must be controlled. Class C3S1 characterizes the wells located in the North and Centre of the region with a percentage of $71,42 \%$;

- Classes C4S2, C4S3 indicate poor water with high mineral content, which may be suitable for irrigation of certain salt-tolerant species and on well-drained and leached soils. They are found in groundwater recharge areas and areas at potential risk of saline bevel intrusion with a percentage of $7,15 \%$;

- Class C5S4: water not recommended for irrigation $2,86 \%$.

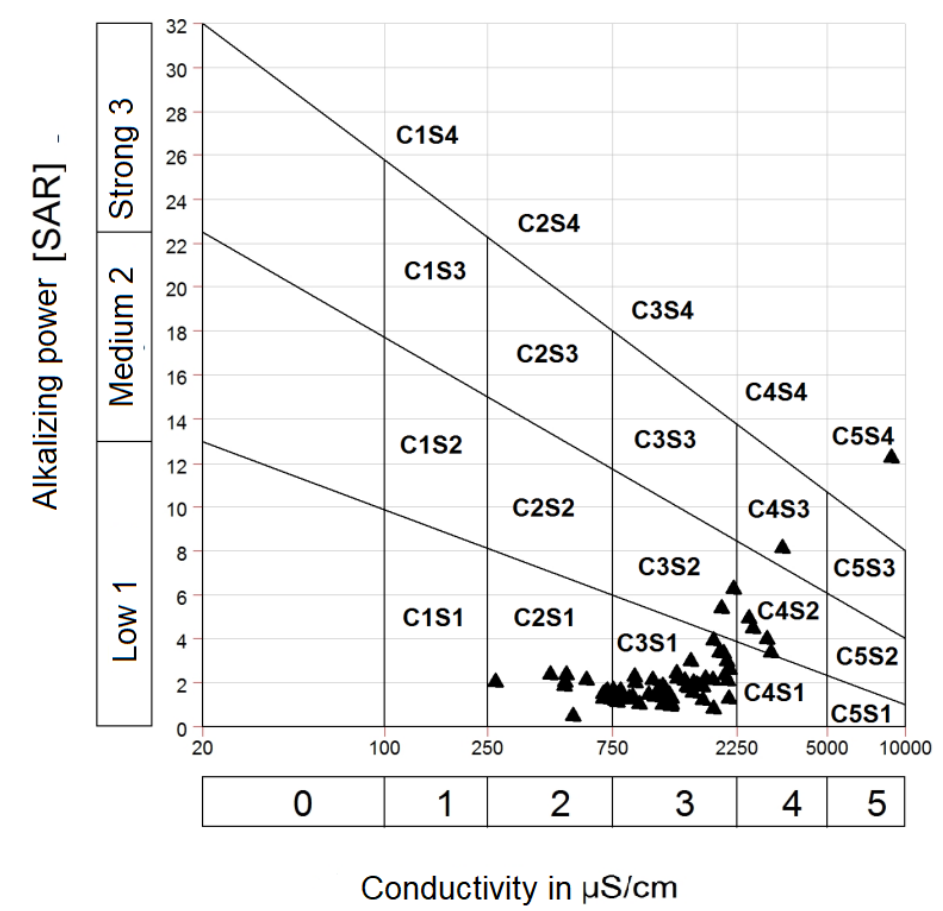

Figure 6. Riverside diagram of groundwater in the Mnasra aquifer

The MAR results showed that 54 wells have concentrations below 50 and can, therefore, be used for irrigation (Figure 7). Nevertheless, 16 wells are unsuitable for irrigation due to high magnesium contents and are likely to lead to soil salinization and reduced fertility, thus reducing crop yields.

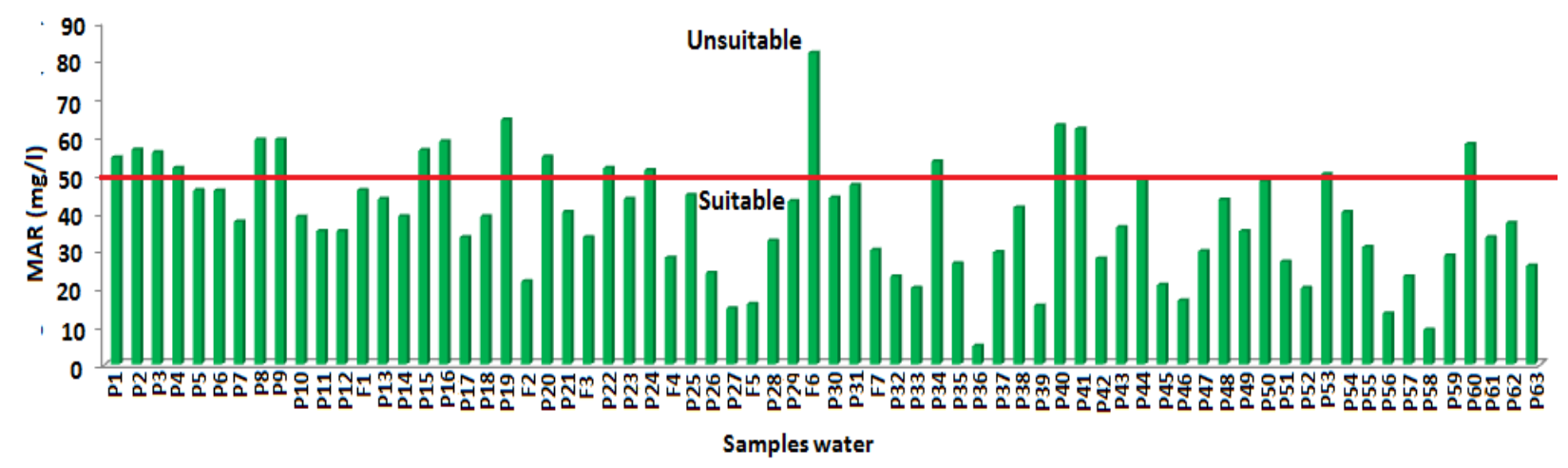

Figure 7. Comparison of magnesium adsorption ratio Mnasra in aquifer groundwater with WHO standards 
The SSP values obtained showed that 58 wells are favourable to irrigation, and 12 wells have concentrations higher than 50 and therefore unusable for irrigation purposes (Figure 8).

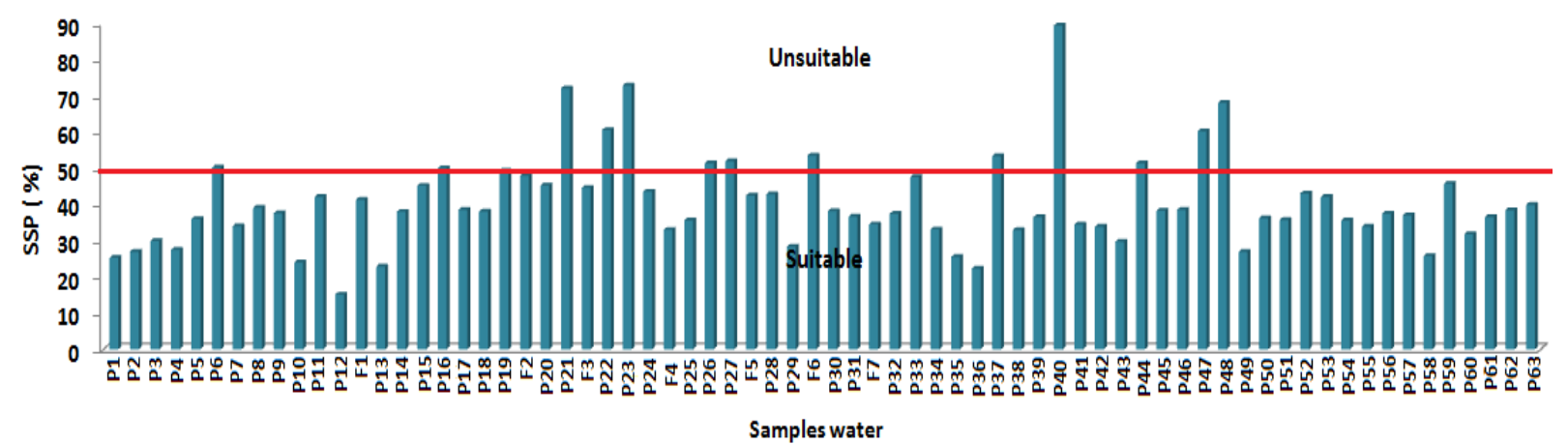

Figure 8. Comparison of soluble sodium percentage in Mnasra aquifer groundwater with WHO standards

The calculation of TDS values indicates that all samples are fresh (61 wells) and slightly saline
(7 wells) (Figure 9). For all water samples analysed.

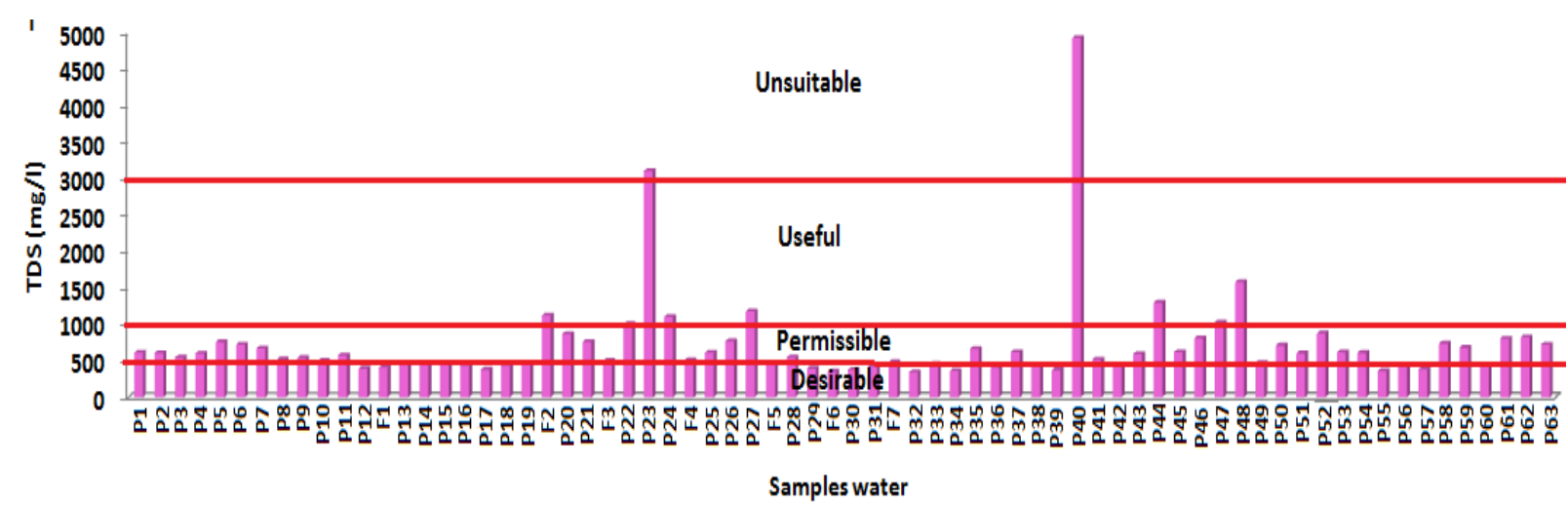

Figure 9. Comparison of total dissolved salts in Mnasra aquifer groundwater with WHO standards

The RSC values are low, not exceeding 1, 25 meq/l, carbonates and bicarbonates (Figure 10). which then eliminates the harmful effects of

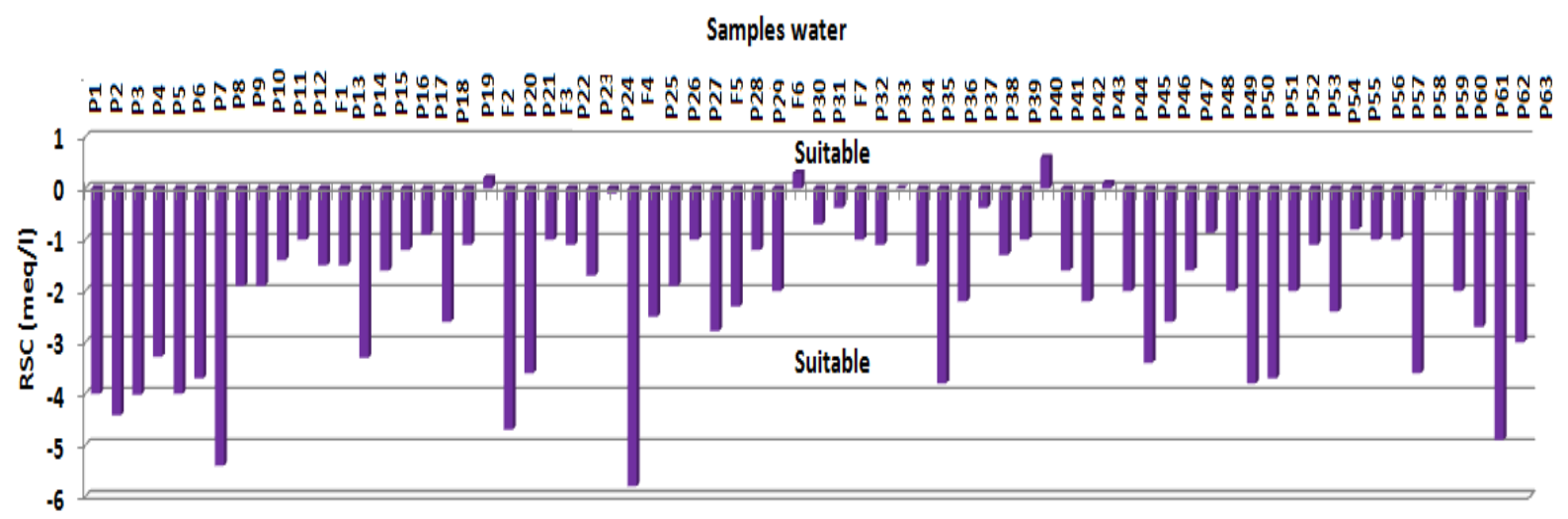

Figure 10. Comparison of residual sodium carbonate in Mnasra aquifer groundwater with WHO standards

The PI values obtained highlighted two classes of category 1 and 2 . They vary between 25 and $75 \%$, which makes their use in irrigation acceptable ${ }^{57}$ (Figure 11). 


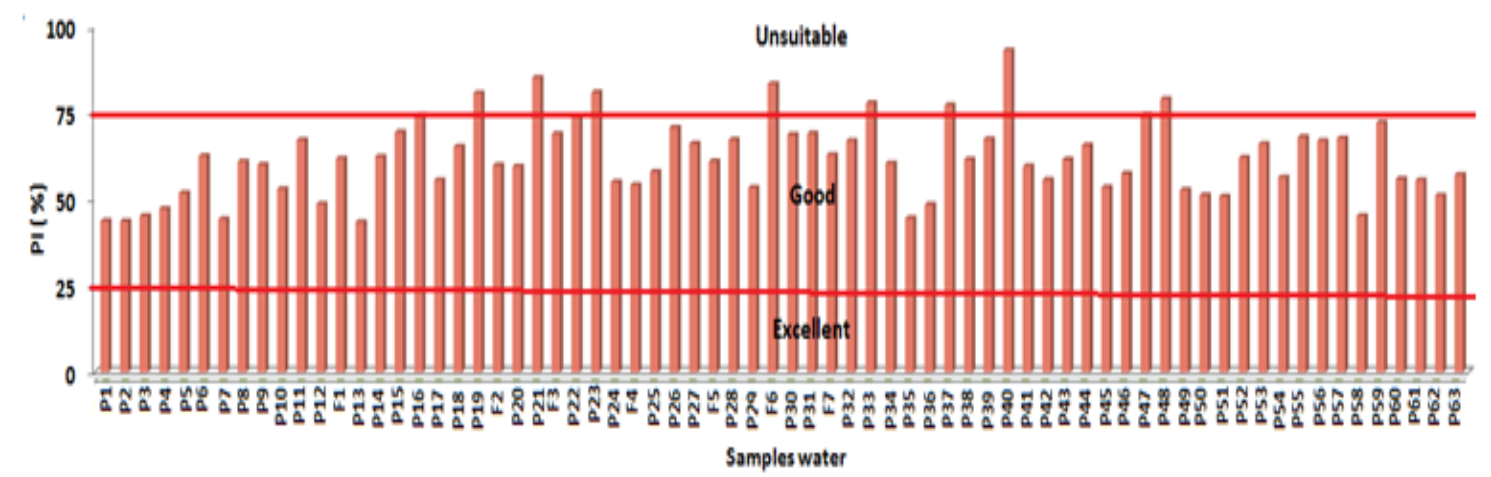

Figure 11. Comparison of permeability index in Mnasra aquifer groundwater with WHO standards

The presence of salts in groundwater directly affects plant growth, soil structure, permeability and aeration $^{58}$. The results of $\%$ Na show excellent quality at a single well, 40 water points have good quality, 20 wells represent acceptable quality, and only 9 wells report poor quality (Figure 12).

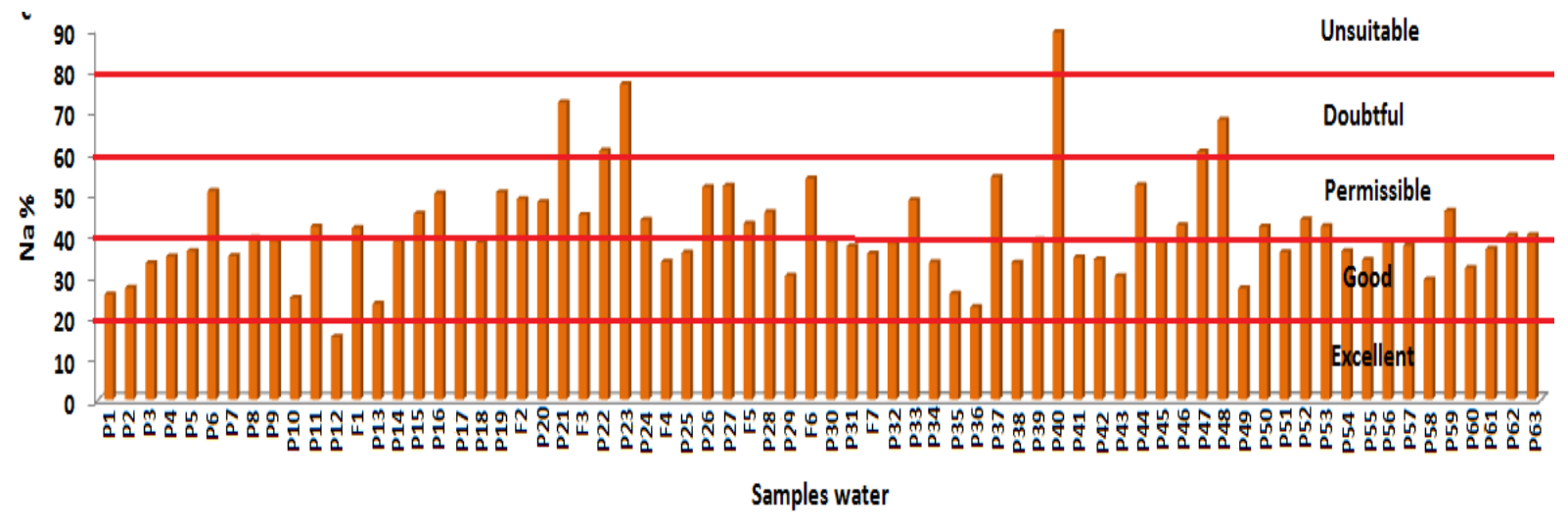

Figure 12. Comparison of percentage of sodium in Mnasra aquifer groundwater with WHO standards

Based on the overall salinity and \% $\mathrm{Na}$, the Wilcox diagram showed that $22,86 \%$ of groundwater samples are of excellent quality for irrigation; $52,86 \%$ of cases of good quality; $5,71 \%$ of cases are within the acceptable level; $12,86 \%$ of water points indicate poor quality and $5,71 \%$ of samples with poor quality.

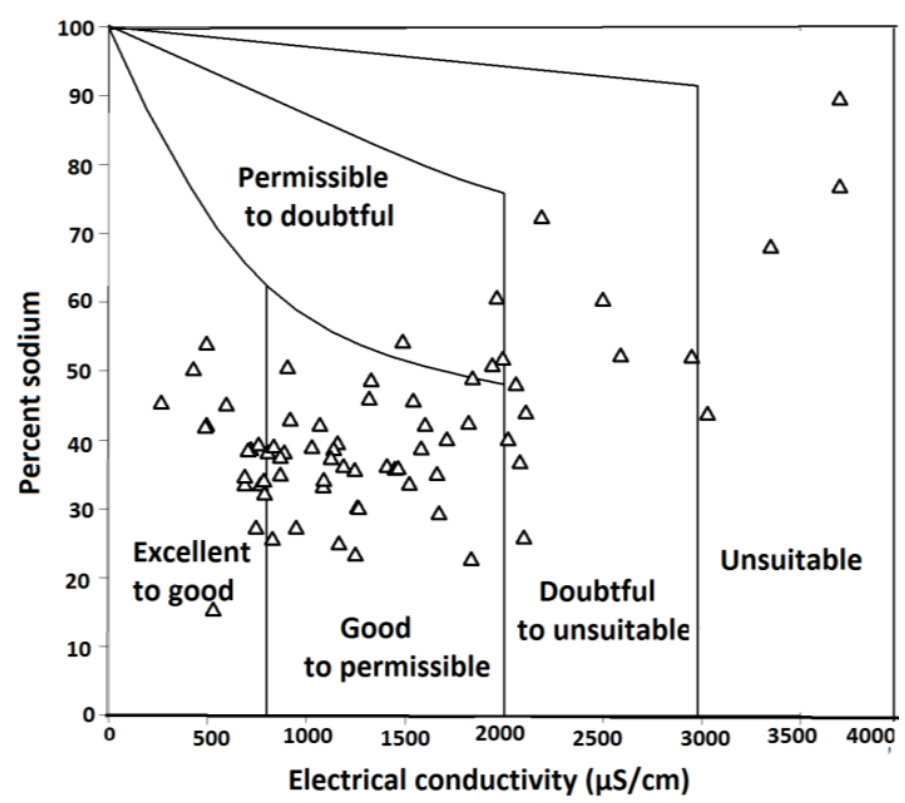

Figure 13. Wilcox diagram of groundwater in the Mnasra aquifer 
The spatial distribution maps of the SAR, MAR, $\% \mathrm{Na}, \mathrm{SSP}, \mathrm{RSC}$ and TDS of the study area, presented in Figures $8 \mathrm{a}, 8 \mathrm{~b}, 8 \mathrm{c}, 8 \mathrm{~d}$, 8e and 8f, revealed that it is the water points located in the south-east of the plain and near Oued Sebou that have significantly exceeded the allowable limits. This is because these waters are included in areas of vulnerability, such as saline bevel intrusion zones and groundwater recharge zones.

As a result, the use of these water points for agricultural purposes may weaken the physical properties of the soil, particularly the structure. Moreover, the Mnasra region is characterized by the dominance of the sandy-clay and silty-clay texture. This type of texture favours the adsorption of $\mathrm{Na}$ on the clay-humic complex.

This raises problems of degradation of the physical and chemical properties of soils, therefore, the decrease in fertility which leads to a reduction in crop yields and sometimes even the disappearance of the plant cover. a
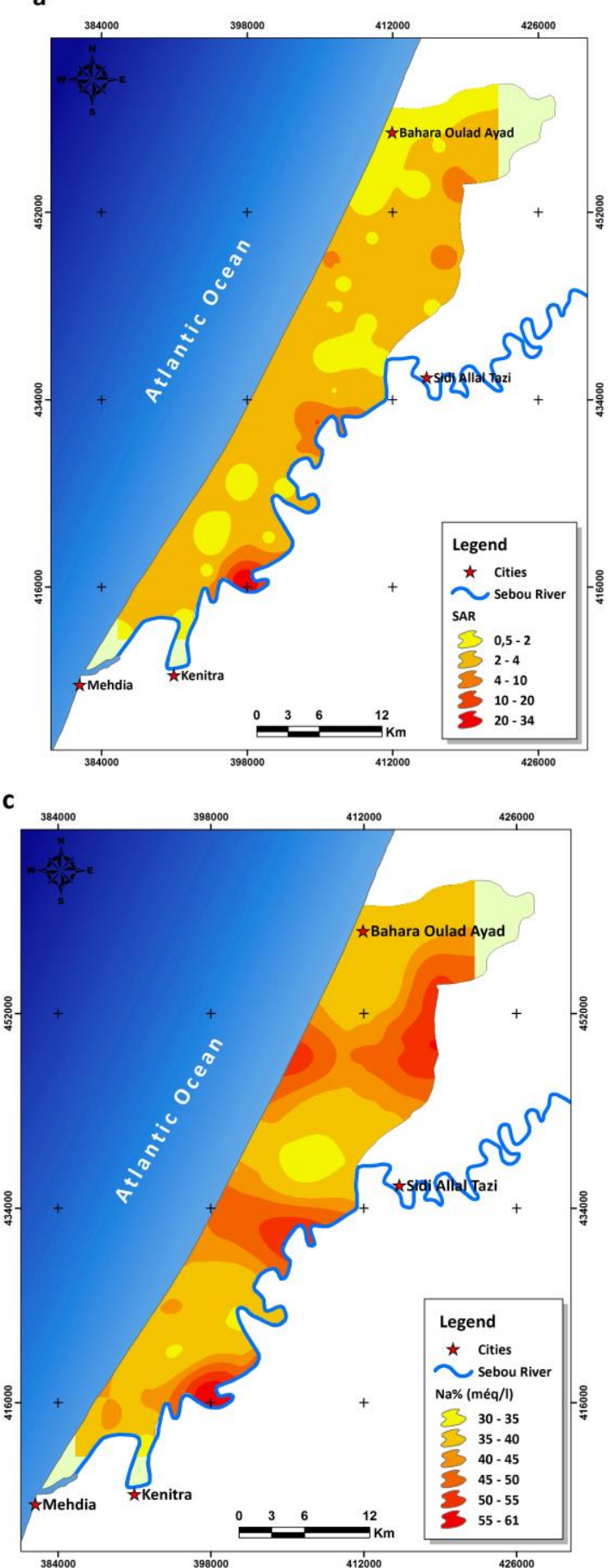

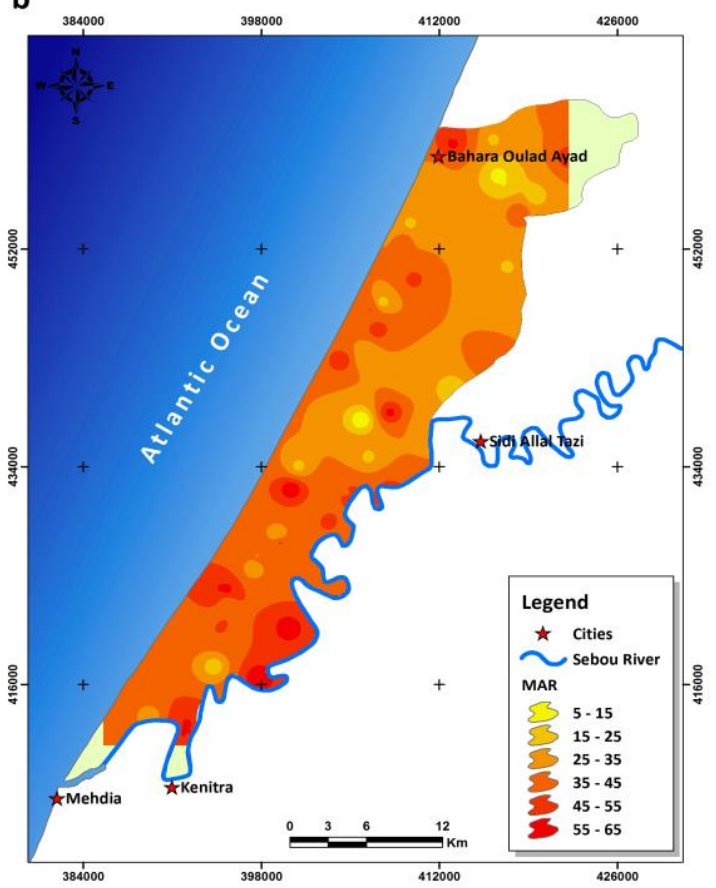

d

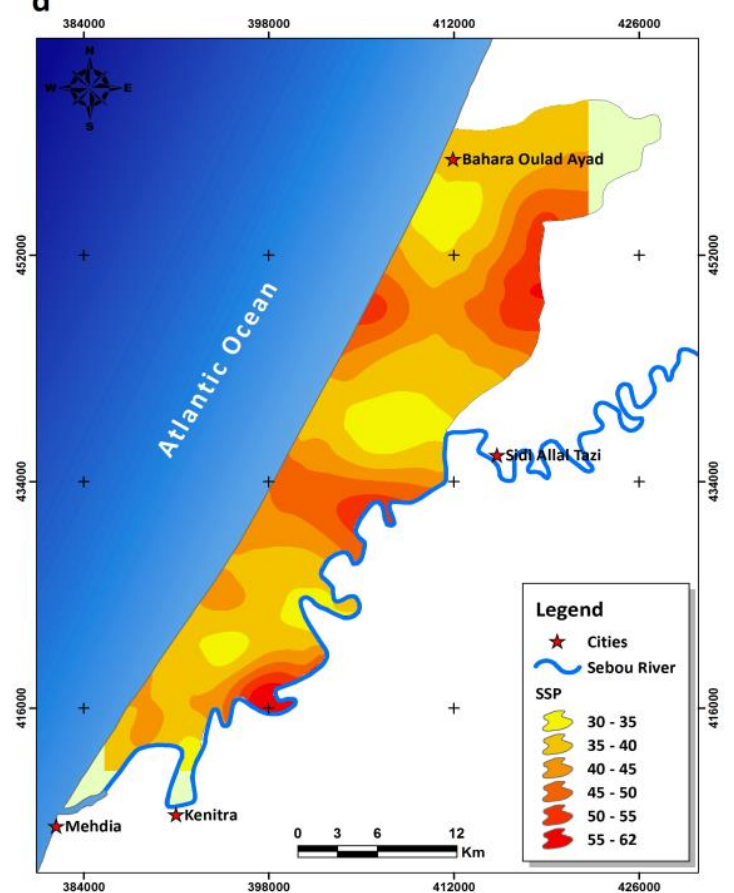



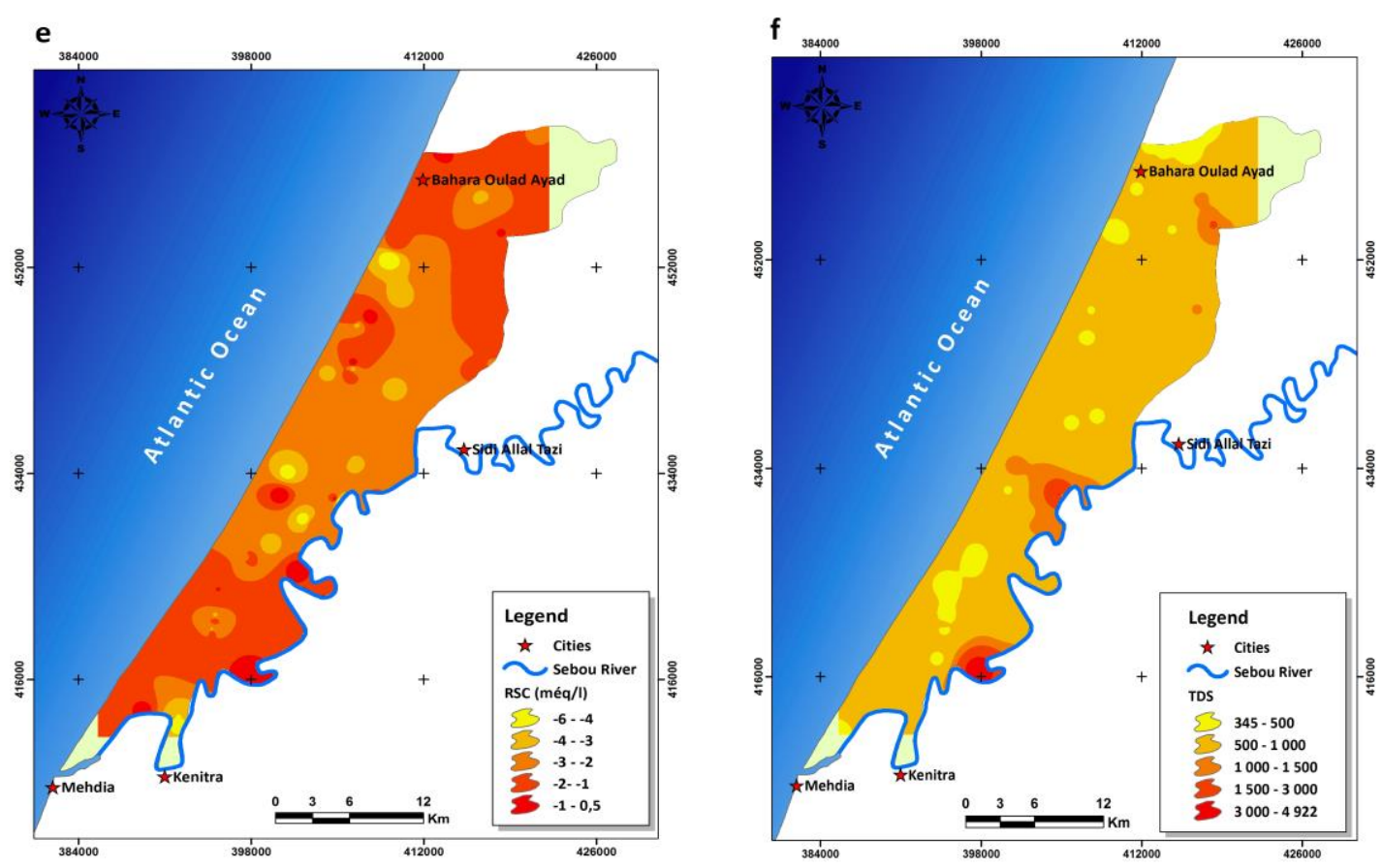

Figure 14. Spatial distribution of qualitative elements of irrigation

\section{Conclusion}

Physico-chemical parameters and hydrochemical methods were used to characterize the quality of Mnasra groundwater used in irrigation. The study was based on 70 well water samples. The results revealed relatively variable physicochemical characteristics. The Piper diagram identified two facies: calcic and magnesic chlorinated $(85,70 \%)$, and a chlorinated sodium facies $(14,30 \%)$. Stuyfzand's classification showed that the waters are fresh to fresh-brackish, of moderate alkalinity. These classes reflect the basic exchanges between waters and clay minerals. The spatial distribution of chemical parameters revealed that high concentrations of $\mathrm{Cl}, \mathrm{Na}, \mathrm{HCO}_{3}$ and $\mathrm{Ca}$ are recorded downstream of the Sebou River and in the northeast of the region; this is due to the calcareous nature of the aquifer. The analysis of water quality indicators for irrigation use has shown, overall, good quality for agricultural purposes. However, in the semi-arid context and particularly in the soil conditions of the study area, this water could be used for irrigation under conditions of proper management and cultural practices, including the adoption of salttolerant crops, the practice of leaching. In addition, it should be noted that the water from the wells located around the Sebou River and in the north-east zone of the plain has areas of vulnerability due to the existence of a saline bevel and a groundwater recharge zone par excellence.

\section{Recommendations}

- Development of irrigation methods, and management and planning of estimated plan irrigation according to climate demand, water quality, soil types, crops and stages of development. Taking into account the water potential and the valuation of the cubic meter of water;

- Development of drainage techniques, leaching fractions and techniques aimed at combating salinity (improvements) by promoting hydro-agricultural development and monitoring of evaluation: The drainage of irrigated land is very important to control and reduce the salinization of the soil, the drainage water must be drained safely so that it can be recycled by installing treatment plants. Admittedly, the costs of installing drainage are enormous, but natural or artificial drainage is compulsory and must regularly provide doses of leaching to keep the saline composition of the soil solution close to that of the irrigation water;

- Use of mathematical simulation models for efficient management of water irrigation, with control of soil salinity and crop yields;

- The recent pedological study of all the soils in the region appears to be essential and more than necessary makes it possible to identify a certain number of specific characteristics linked to cultivation. The aim is to map soils in order to classify soils favorable to development;

- To better enhance our research work, and as long as the Mnasra region is a pioneer region with an agricultural vocation, the multiplication of the number of weather stations appears more than necessary in order to mastery and control the water balance (ETP, and rain/irrigation).

\section{References}

1- B. Agoubi, A. Kharroubi, H. Abida, Hydrochemistry of groundwater and its 
assessment for irrigation purpose in coastal Jeffara Aquifer, southeastern Tunisia. Arabian Journal of Geosciences, 2013, 6(4), 1163-1172.

2- R. Majdoub, M. Hachicha, A. El Amri, M. Melki, Etude de la dynamique de l'eau et du transfert des sels dans un sol sablo-limoneux du Sahel Tunisien. Eur. J. Sci. Res., 2012, 80, 499-507.

3- M. Achite, S. Rezak, A. Benbouali, Contribution à l'étude de la qualité des eaux d'irrigation en zone semi-aride. Cas de la plaine de Ghriss (wilaya de Mascara). In 54 th International Excutive Council of ICID, 2003, 20th ICID European Conference.

4- M. Zeraouli, M. Morchid, Fertilisation azotée du poivron sous tunnel dans une zone sableuse à nappe proche de la surface. Rev. Marocaine des Sciences et Technique du Développement Rural, $\mathrm{N}^{\circ}$ ISSN 03739554, $31^{\text {ème }}$ Année, 2001, 31 -118, (03), 34-36.

5- M. Eissa, M. Hussein Hosni , O. Shouakar-Stash, A. El-Shiekh, B. Parker, Geophysical and geochemical studies to delineate seawater intrusion in Bagoush area, Northwestern coast, Egypt, Journal of African Earth Sciences, 2016, $121,365-381$.

6- T. Keesari, K. L. Ramakumar, S. Chidambaram, S. Pethperumal, R. Thilagavathi, Understanding the hydrochemical behavior of groundwater and its suitability for drinking and agricultural purposes in Pondicherry area, South India- A step towards sustainable development, Groundwater for Sustainable Development, 2016, 2, 143-153.

7- A. Das, F. Munoz-Arriola, S. K. Singh, P. K. Jha, M. Kumar, Nutrient dynamics of the Brahmaputra (Tropical River) during the monsoon period, Desalin Water Treat Sci Eng, 2017, 76, 212-224.

8- A. Amin, S. Fazal, A. Mujtaba, S. K. Singh, Effects of land transformation on water quality of Dal lake, Srinagar, India, J Indian Soc Remote Sens, 2014, 42, 119-128.

9- P. K. Srivastava, S. K. Singh, M. Gupta, J. K. Thakur, S. Mukherjee, Modeling impact of land use change trajectories on groundwater quality using remote sensing and GIS, Environ Eng Manag J, 2013, 12(12), 2343-2355.

10-S. Gajbhiye, S. K. Singh, S. K. Sharma, Assessing the effects of different land use on water qualify using multi-temporal landsat data. Resource Management and Development Strategies: A Geographical Perspective, 2015, 21, $337-348$.

11-J. Nemčić-Jurec, S. K. Singh, A. Jazbec, S. K. Gautam, I. Kovac, Hydrochemical investigations of groundwater quality for drinking and irrigational purposes: two case studies of Koprivnica-Križevci County (Croatia) and district Allahabad (India), Sustainable Water Resources Management, 2017, 5, 467-490.

12-K. S. Rawat, V. K. Tripathi, S. K. Singh, Groundwater quality evaluation using numerical indices: a case study (Delhi, India), Sustainable Water Resources Management, 4, 875-885.

13-K. S. Rawat, S. K. Singh, Water quality indices and GIS-based evaluation of a decadal groundwater quality, Geology, Ecology, and Landscapes, 2018, 2(4), 240-255.

14-M. Vasanthavigar, K. Srinivasamoorthy, K. Vijayaragavan, R. Rajiv Ganthi, S. Chidambaram, V. S. Sarama, P. Anandhan, R. Manivannan, S. Vasudevan, Application of water quality index for groundwater quality assessment: Thirumanimuttar Sub-Basin, Tamilnadu, India, Environ Monit Assess, 2010, 171(1-4), 595-609.

15-M. Milovanovic, Water quality assessment and determination of pollution sources along the Axios/Vardar River, Southeast Europe. Desalination, 2007, 213(1-3), 159-173.

16-P. Gupta, M. Vishwakarma, P. M. Rawtani, Assessment of water quality parameters of Kerwa Dam for drinking suitability, International Journal of Theoretical \& Applied Sciences, 2009, 1(2), 53-55.

17-T. G. A. Jacintha, K. S. Rawat, A. Mishra, S. K. Singh, Hydrogeochemical characterization of groundwater of Penninsular Indian region using multivariate statistical techniques, Applied Water Science, 7(6), 3001-3013.

18-K. S. Rawat, S. K. Singh, T. G. A. Jacintha, J. Nemčić-Jurec, V. K. Tripathi, Appraisal of long term groundwater quality of peninsular India using water quality index and fractal dimension, Journal of Earth System Science, 2018, 126(8), 126-122.

19-S. K. Gautam, E. Tziritis, S. K. Singh, J. K. Tripathi, A. K. Singh, Environmental monitoring of water resources with the use of PoS index: a case study from Subarnarekha River basin, India, Environmental earth sciences, 2018, 77(7), 70.

20-S. K. Gautam, D. Sharma, J. K. Tripathi, S. Ahirwar, S. K. Singh, A study of the effectiveness of sewage treatment plants in Delhi region. Applied Water Science, 2013, 3(1), 57-65.

21-S. K. Singh, P. K. Srivastava, A. C. Pandey, S. K. Gautam, Integrated assessment of groundwater influenced by a confluence river system: concurrence with remote sensing and geochemical modelling, Water resources management, 2013, 27(12), 4291-4313.

22-S. K. Singh, P. K. Srivastava, D. Singh, D. Han, S. K. Gautam, A. C. Pandey, Modeling groundwater quality over a humid subtropical region using numerical indices, earth observation datasets, and X-ray diffraction technique: a case study of Allahabad district, India, Environmental geochemistry and health, 2015, 37(1), 157-180.

23-L. A. Richard, Diagnosis and improvement of saline alkali soils. Agric. Handbook 60, US Department of Agriculture, Washington DC, 1954, 160. 
24-S. Singh, C. Singh, K. Kumar, R. Gupta, S. Mukherjee, Spatial-temporal monitoring of groundwater using multivariate statistical techniques in Bareilly district of Uttar Pradesh, India, Journal of Hydrology and Hydromechanics, 2009, 57(1), 45-54.

25-M. Combe, Le bassin Gharb-Maâmora et les petits bassins septentrionaux des oueds Dradère et Souieire. Ressources en eau du Maroc, Tome 2, plaines et bassin du Maroc Atlantique. Notes et Mem. Serv. Géol. Maroc, 1975, 231, 93-145.

26-Scet-Maroc. Projet de Protection de l'Environnement du bassin de Sebou (PPBS). Etude pour un programme d'action visant à minimiser et à contrôler l'impact des engrais et des pesticides sur l'environnement du bassin de Sebou. Sous-mission 2.1. Secrétariat d'Etat Chargé de l'Environnement 1999.

27-M. Zeraouli, M. Mrini, Fertilité des Sols et Fertilisation Potassique des principales Cultures dans la Région du Gharb (Maroc) Développement de la fertigation. IPI regional workshop on potassium and fertigation development in West Asia and North Africa, Rabat, Morocco, 24-28 November 2004.

28-B. Marouane, Transfert des nitrates et des pesticides dans les sols de la région du GharbEtude à l'échelle de la parcelle, Thèse de Doctorat. Université Mohammed V. Rabat, Maroc, 2014.

29-J. Rodier, L'analyse de l'eau : eaux naturelles, eaux résiduaires, eau de mer : chimie, physicochimie, bactériologie, biologie, Dunod, 1975.

30-M. M. Bahar, S. M. Reza, Hydrochemical characteristics and quality assessment of shallow groundwater in a coastal area of Southwest Bangladesh, Environmental Earth Sciences, 2009, 61, 1065-1073.

31-J. Rodier, L'analyse de l'eau, eaux naturelles, eaux résiduaires, eau de mer, 9th, 2009.

32- F. H. Azaza, M. Ketata, R. Bouhlila, M. Gueddari, Hydrogeochemical characteristics and assessment of drinking water quality in Zeuss-Koutine aquifer, southeastern Tunisia, Environ. Monit. Assess., 2011, 174, 283-298.

33-R. A. Freeze, J. A. Cherry, Groundwater. Englewood Cliffs: Prentice Hall, New Jersey, 1979, 7632, 604.

34-A. M. Piper, A graphic Procedure in the Geochemical Interpretation of Water-Analyses, Eos, Transactions American Geophysical Union, 1944, 25, 914-928.

35-P. J. Stuyfzand, A new hydrochemical classification of watertypes, Iahs Publ., 1989, 182, 89-98.

36-P. N. Mollema, M. Antonellini, E. Dinelli, G. Gabbianelli, N. Greggio, P. J. Stuyfzand, Hydrochemical and physical processes influencing salinization and freshening in Mediterranean low-lying coastal environments, Applied Geochemistry, 2013, 34, 207-221.
37-S. Khalid, An assessment of groundwater quality for irrigation and drinking purposes around brick kilns in three districts of Balochistan province, Pakistan, through water quality index and multivariate statistical approaches, J. Geochem. Explor., 2019, 197, 14-26.

38-P. Tahmasebi, M. H. Mahmudy-Gharaie, F. Ghassemzadeh, A. K. Karouyeh, Assessment of groundwater suitability for irrigation in a gold mine surrounding area, NE Iran, Environmental earth sciences, 2018, 77, 766.

39-H. M. Raghaunth, Groundwater Hydrology, Wiley Eastern Ltd, New Delhi, 1989.

40-L. V. Wilcox, Classification and use of irrigation waters, U.S. Department of Agriculture, 1955.

41-I. D. Doneen, Notes on water quality in agriculture, University of California, Davis, 1964.

42-J. M. Dhirendra, K. Alok, A. Namita, Assessment of the irrigation water quality of river Ganga in haridwar district, Rasayan journal of chemistry, 2009, 2, 285-292.

43-R. M. Lark, Estimating variograms of soil properties by the method-of-moments and maximum likelihood, European Journal of Soil Science, 2000, 51, 717-728.

44-I. Triki, I. Hentati, N. Trabelsi, M. Zairi, Evaluation de techniques d'interpolation spatiale de la piézométrie à l'aide de l'extension Geostatistical Analyst d'ArcGIS, Géomatique Expert, 2014, 90, 55-63.

45-H. Schöeller, Les Eaux Souterraines : Hydrologie dynamique et chimique, Recherche, Exploitation et Évaluation des Ressources, Paris, 1962, 642.

46-J. A. Sayyed, A. B. Bhosle, Analysis of chloride, sodium and potassium in groundwater samples of Nanded City in Mahabharata, India, Eur. J. Exp. Biol., 2011, 1, 74-82.

47-P. Singh, I. A. Khan, ground water quality assessment of Dhankawadi ward of Pune by using GIS, Int. J. Geomat. Geosci., 2011, 2, 688-703.

48-V. Chaudhary, S. Satheeshkumar, Assessment of groundwater quality for drinking and irrigation purposes in arid areas of Rajasthan, India, Applied Water Science, 2018, 8, 218.

49-K. Srinivasamoorthy, M. Gopinath, S. Chidambaram, M. Vasanthavigar, V. S. Sarma, Hydrochemical characterization and quality appraisal of groundwater from Pungar sub basin, Tamilnadu, India, Journal of King Saud University Science, 2014, 26, 37-52.

50-C. A. J. Appelo, D. Postma, A. A. Balkema, Geochemistry, groundwater and pollution, Brookfield, 1993,

51-Y. Mtoni, I. C. Mjemah, C. Bakundukize, M. V. Camp, K. Martens, K. Walraevens, Saltwater intrusion and nitrate pollution in the coastal aquifer of Dar es Salaam, Tanzania, Environmental Earth Sciences 2013, 70, 1091-1111. 
52-B. Capaccioni, M. Didero, C. Paletta, L. Didero, Saline intrusion and refreshening in a multilayer coastal aquifer in the Catania Plain (Sicily, Southern Italy): dynamics of degradation processes according to the hydrochemical characteristics of groundwaters, Journal of Hydrology, 2005, 307, 1-16.

53-R. Djamaï, D. Fadel, A. Laïfa, M. Benslama, Y. Daoud, V. Vallès, Le concept d'alcalinité résiduelle et évolution géochimique des processus. Application aux sols salés du lac Fetzara (Nord-Est algérien), Revue des Sciences et de la Technologie, 2011, 23, 90-98.

54-A. Bouchaib, Etude géochimique et isotopique des principaux aquifères du bassin Crétacé d'Errachidia et de la plaine de Tafilalet, Thèse de Doctorat d'état. Université Mohammed V. Rabat, Maroc, 2007.
55-K. Ramesh, L. Elango, Groundwater quality assessment in Tondiar basin, Indian, J. Environmental Protection, 2006, 26, 497-504.

56-R. Shabbir, A. S. Saeed, Use of Geographic Information System and Water Quality Index to Assess Groundwater Quality in Rawalpindi and Islamabad, Arabian Journal for Science and Engineering, 2015, 40 (7), 2033-2047.

57- A. K. Singh, G. C. Mondal, S. Kumar, T. B. Singh, B. K. Tewary, A. Sinha, Major ion chemistry, weathering processes and water quality assessment in upper catchment of Damodar River basin, India. Environ. Geol, 2008, 54 (4), 745-758.

58 -I. D. Doneen, Notes on water quality in agriculture. Davis: Water Science and Engineering, University of California, 1964, 48p. 